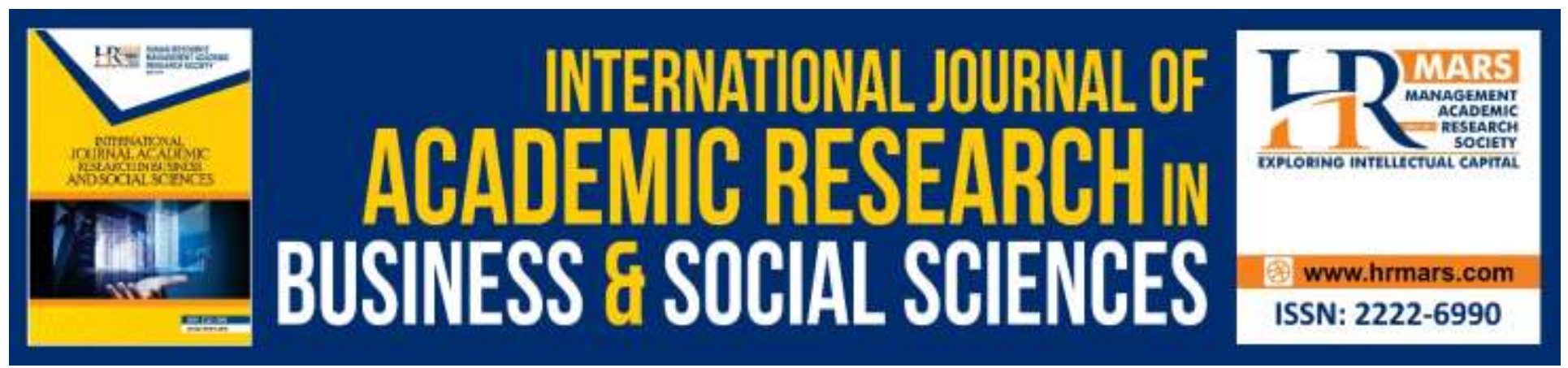

\title{
The Influence of Asset Quality on Sustainability of Kenya's Insurance Companies
}

Johannes Mwangangi Kitaka, David Kiragu, Simmy M. Marwa

To Link this Article: http://dx.doi.org/10.6007/IJARBSS/v10-i5/7242

DOI:10.6007/IJARBSS/v10-i5/7242

Received: 07 March 2020, Revised: 16 April 2020, Accepted: 19 April 2020

Published Online: 29 May 2020

In-Text Citation: (Kitaka et al., 2020)

To Cite this Article: Kitaka, J. M., Kiragu, D., \& Marwa, S. M. (2020). The Influence of Asset Quality on Sustainability of Kenya's Insurance Companies. International Journal of Academic Research in Business and Social Sciences, 10(5), 697-713.

Copyright: (C) 2020 The Author(s)

Published by Human Resource Management Academic Research Society (www.hrmars.com)

This article is published under the Creative Commons Attribution (CC BY 4.0) license. Anyone may reproduce, distribute, translate and create derivative works of this article (for both commercial and non-commercial purposes), subject to full attribution to the original publication and authors. The full terms of this license may be seen at: http://creativecommons.org/licences/by/4.0/legalcode

Vol. 10, No. 5, 2020, Pg. $697-713$

http://hrmars.com/index.php/pages/detail/IJARBSS

JOURNAL HOMEPAGE

Full Terms \& Conditions of access and use can be found at http://hrmars.com/index.php/pages/detail/publication-ethics 


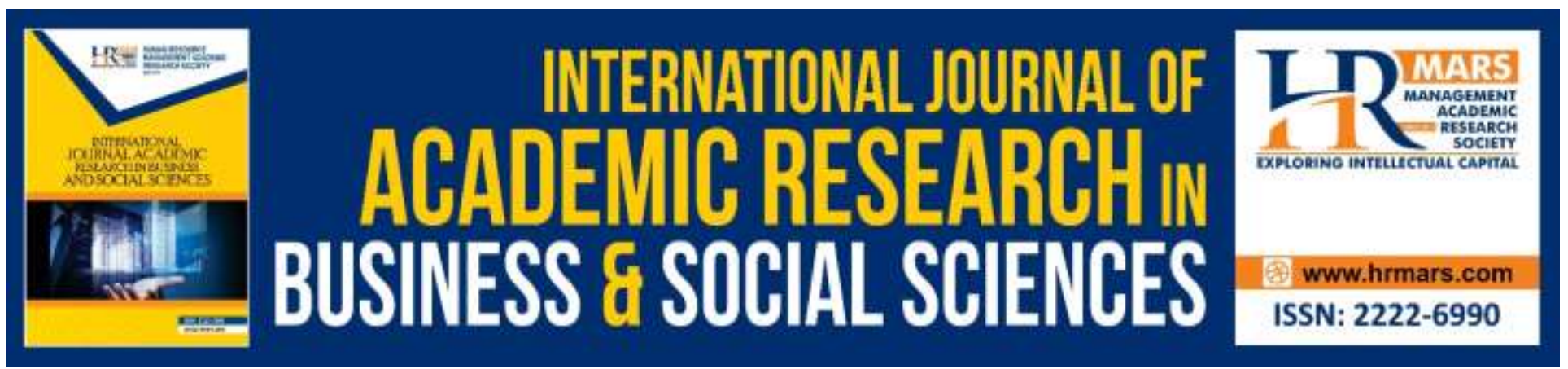

\title{
The Influence of Asset Quality on Sustainability of Kenya's Insurance Companies
}

\author{
Dr. Johannes Mwangangi Kitaka (PhD), Prof. David Kiragu (PhD), \\ Prof. Simmy M. Marwa (PhD).
}

Department/School: School of Business Management \& Economics, Dedan Kimathi University of

Technology, Nairobi, Kenya.

Email.joekyutu67@gmail.com,drkiragu@gmail.com / dkiragu@dkut.ac.ke, mwitamarwa@yahoo.com / simmy.marwa@dkut.ac.ke

\begin{abstract}
Purpose: To examine how asset quality influence the sustainability of insurance companies in Kenya. Methodology: The study adopted a positivist research philosophy and employed a descriptive research design during the research process. The target population was the 51 insurance companies as registered by the Insurance Regulatory Authority of Kenya (IRA) as at $31^{\text {st }}$ December 2016 . The study proportionately chose 30 companies, of which 10 companies were life, 15 from general and 10 from composite insurance companies' respectively. The raw data was cleaned, edited, coded and analyzed using SPSS analytical tool to generate descriptive and inferential statistics while secondary data was collected using data collection sheets. Data analysis was performed using multiple regression analysis to determine the relationship of the independent variable of Asset Quality to the dependent variable of Sustainability. The researcher used descriptive statistics such as the mean, the standard deviation and frequencies to analyze the data. Further, inferential statistics such as the ANOVA and the T-test were applied for further analysis.

The Study Findings: Asset quality had a positive and significant effect on sustainability of insurance companies in Kenya. The insurance companies that list defaulting clients with credit reference bureaus ended up improving the quality of premiums debtors, which bring in a significant impact on sustainability. Further, a company listing of defaulting clients with the credit reference bureaus and the elevation of credit management to both senior management and board levels were all positive and significant to company sustainability. However, both having a credit control policy and annual credit rating exercises had insignificant influence on asset quality and therefore its influence on sustainability of insurance companies were diminished.
\end{abstract}

Unique Contribution: Recent trends show many international insurance companies from Europe and South Africa making entry into the country. The entry of these companies is key as they make significant contributions to the insurance sector such as foreign direct investments in various local insurance companies. The result has been merging and acquisition of various local companies by large companies like Old Mutual and Absa Bank. These acquisitions are positive in nature since they will 
bring additional underwriting and reinsurance capacities and capabilities in addition to better risk management. However, the interest by foreign insurance companies, some of which had long exited the Kenyan insurance market is a threat to the long established local insurance company owners. Therefore, IRA should ensure adequate regulation to safeguard the industry against companies that may come in and siphon out capital in terms of transfer pricing and management agreements without proper regulatory supervision. Further, the various efforts by the government to regulate the insurance industry were found not to influence the quality of capital that an insurance company has, as there has been significant non-compliance to many of the guidelines that enhance asset quality.

Keywords: Asset Quality, Sustainability, Insurance Companies.

\section{Introduction}

The main aim was to examine the influence of asset quality on sustainability of insurance companies in Kenya. A review of the IRA of Kenya (2001-2015) reports show that the general insurance premiums in the country have grown significantly during the period under study, increasing to Ksh 110 Billion in 2015 from Ksh 16 Billion in 2001. Despite the sevenfold increase in top line, the ratio of net earned premiums to gross written premiums has remained constant at $72 \%$, the ratio of claims costs, net commissions and management expenses to net earned premiums respectively have been on the rise, leading to a near flat or decline in underwriting profits during the same period. The dismal and unsatisfactory performance is attributable to poor management and inappropriate risk management practices such as price undercutting, high fraud levels, and the management's inability to propagate the use of insurance as an alternative investment vehicle leading to low insurance awareness by customers. The IRA of Kenya is addressing some of these factors through customer education and regulation though with limited success as the insurance penetration remains low, at $2.73 \%$ compared to many developing and developed countries.

In addition, the industry loss ratio, which is measured by dividing net claims incurred by net earned premiums, remained at $60 \%$ while net commission's expenses as a percentage of Net Earned Premium reduced from $15 \%$ to $7 \%$ in 2001 to 2015 . The management expense has remained constant at $31 \%$ during the period understudy and therefore, the underwriting margin has been erratic, depicting a performance, which is vulnerable to various factors, which influence the level of incurred claims, net commissions paid and the expense management. The decline in net commission's expense reflects a controlled regulatory framework where commissions earned from reinsurance arrangements offset the increased commissions paid to distribution channels partners due to growth in gross written premiums. The reduction in net commission ratio may also mean that the business and product mix have remained constant over time reflecting a low level of product and service innovation. The claims incurred and expense management have been growing at a faster rate than the net earned premiums, resulting into an erratic and unpredictable performance. Further, the performance has been poor over the years reporting very low underwriting profit margins and even negative profit margins in some of the years. The ROE and ROA have been erratic though growing faster than inflation and GDP growth rate in most of the years. The insurance industry is a highly regulated, leaving limited choice on available investment vehicles and therefore the returns achieved may not be good enough to attract investment in some of the sectors of the economy.

Kenya has a dynamic insurance industry in Africa although it is quite small by global standards. The insurance industry has experienced persistent growth supported by a growing middle class who have 
continued to support the demand for insurance products and services (IRA, 2015). The industry continues to be innovative in utilizing mobile technology for product distribution and collection of premiums. Micro insurance, which has been developed and rolled out to farmers, is a fast developing product in terms of crop and livestock insurance. In recognition of the vast majority of the Muslim population in Kenya, various insurance companies have come up with Takaful as a product in addition to developing interest in Takaful Insurance products (BMI, 2014a). These product innovations are not enough to push the vast uninsured populace to purchase insurance as a cushion to life and property and casualty uncertainties.

In the last 15 years, seven (7) insurance companies have collapsed. The cause of collapse of the seven companies, which is $16 \%$ of insurance companies in operation at the time, was attributable to inadequate governance structures, assets and liabilities mismatch, rampant fraud and mismanagement. The collapse of the insurance companies caused pain to the population due to loss of employment, loss of taxes to government, loss of invested capital and hence the policyholders could not have their claims paid, or paid on time, thus affecting the social and economic life in the country (IRA, 2015).

The constitution puts sustainability through sustainable development as a national value and principle of governance, binding every citizen and state organ under Article 10(2) (d) of the Constitution of Kenya. Additionally, Article 69(2) of the Constitution commits each citizen to co-work with state organs and different people to secure the environment and guarantee biologically manageable improvement and utilization of assets extracted from the environment. It is evident that insurance companies have a duty to pursue sustainability in their operations and risk management activities from the foregoing provisions in conjunction with Article 3, which requires every citizen to respect, uphold and protect the Constitution (Kariuki, 2015). With the dismally low rate of insurance penetration, at below $2.8 \%$ and trending at $2.5 \%$ against annual turnover growth rates of $13.7 \%$, raises doubt as to the long-term growth prospects of the sector. Insurance industry has the potential to influence people and companies to be sustainable through consistently making underwriting and investment profits.

\section{Problem Statement}

The performance of the insurance industry in Kenya has drastically dropped from a profit of Kes 0.2 million in 2001, to a loss of Kes 0.2 billion in 2015, further deteriorating to Kes 2.3 billion in 2016. This dismal performance with largely no growth at the underwriting level was occasioned by the industry's inability to contain claim costs, high management expenses and acquisition costs. The poor is rendering the industry to be unprofitable and unsustainable. The insurance penetration in Kenya at a low of $2.75 \%$ compared to the global level of $6 \%$ by 2016 shows a dismal performance trend. The low level of insurance penetration is however largely above other regional countries though poor and unsustainable. Many insurance companies have faced persistently poor investment practices and non-compliance to cash and carry law, leading to poor collection of premiums. The slow innovation and adoption to new technology; significant shortage of skilled staff, capital inadequacy, mis-selling by insurance intermediaries and severe price undercutting among the many competitors has led to collapse of 7 companies, representing $16 \%$ of the companies in operation. The collapse of the insurance companies resulted to loss of employment, reduction in taxes paid to the government and loss of shareholder capital. The collapse of the insurance companies meant inability to pay claims in 
INTERNATIONAL JOURNAL OF ACADEMIC RESEARCH IN BUSINESS AND SOCIAL SCIENCES

Vol. 10, No. 5, May, 2020, E-ISSN: 2222-6990 @ 2020 HRMARS

full and at times resulting into ultimate collapse of social and economic pillars of society. The collapse of insurance companies coupled with asset and liability mismatch, rampant fraud and mismanagement necessitated the examination into how asset quality influenced the sustainability of insurance companies in Kenya.

\section{Literature Review}

\section{Theoretical Framework}

In exploring the various sources of capital, and how investors may rank them according to their preferences and consideration of various factors, Myers (1984) concluded that a firm would prefer the use of internally generated sources of capital before turning to external capital. Preference of internally generated funds means that company managers would choose retained earnings as the first source of financing before going out to seek debt financing and therefore leaving financing through equity as the last option. Myers emphasizes that a firm has to balance between tax savings arising out of debt due to interest expense being allowed for tax deductions, decrease in agency costs and financial distress costs as later researched by Uruc (2009).

Danco and Adomako (2014) and Mustafa and Boregowda (2014) investigated capital preference and the tax impact on the same. They argued for and supported the tradeoff theory stresses out the benefit that a firm will achieve through the tax shield enjoyed out of the interest levied on debt being allowable for tax deduction purposes during tax computation being off-set by the company's cost of financial distress and agency. When the probability that a firm will default on financing increases, then there is cost to it and that is the cost of bankruptcy. As companies face bankruptcy, an additional cost of liquidation, may arise involving cost of lawyers, accountants, and even auctioneers who will eventually be involved in the recovery process in case of default. Chen (2011) believes that stakeholders may come to assume that a firm will discontinue its operations once it faces bankruptcy. Debt capital is one of the sources of capital for a firm. Debt has various benefits and associated costs. The firm measures the borrowing costs against the advantages of debt financing while at the same time utilizing the tradeoff hypothesis of the firm. The cost of borrowing incorporates debt installment payments and liquidation costs. The advantage of debt financing incorporates the duty of management to make installment payments which instills discipline on management to ensure they exercise due diligence in the management of the companies. The tradeoff theory asserts that the value of the firm is equivalent to the estimation of unlevered firm in addition to the estimation of the expense shield and the normal expenses because of budgetary trouble (Brigham \& Ehrhardt, 2005).

Companies with lower level of debt financing or even those with no debt financing at all face lower or insignificant probability of insolvency. Baxter (2007) avers that the broad utilization of debt financing increases the likelihood of liquidation, which makes providers of capital to request for additional premium in terms of interest charge. He therefore recommends that organizations not to utilize debt past the point where the cost of obligation is bigger than the tax shield value. As obligation financing expands, the normal insolvency related costs increase and lessens the tax shield advantages of the obligation.

In the life of a company, it is key to establish its optimal debt level. The trade-off theory defines the point of optimal debt-equity mix to be where the negligible tax shield advantage is equivalent to minimal insolvency related expenses. Accordingly, companies ought to incline themselves towards use of equity up to the point where the likelihood of money related trouble and where insolvency 
costs begins to be vital. Bas, Muradoglu and Phylaktis (2009) proposed that the proposed optimal positon could be material for large companies who can create higher benefits. Small companies, which are less likely to have high profits, may not have an option to choose debt financing for the tax shield value may not be sufficient to cover the interest rate charges as result of the debt (Pettit \& Singer, 2005) thereby having the theory inform capital adequacy as an independent variable.

As companies operate and grow, there are times and periods when they are vulnerable to various business factors. These factors may trigger financial distress in the operations of the company. The financial distress theory asserts that financial distress occurs in four stages, namely; company performance deterioration, failure, insolvency and the company going through various default intervals. Whereas deterioration of performance and company failure affect the company's profitability, the company's insolvency and frequent occurrence of default are caused by its level of liquidity. Theoretically, the outcome of each financial distress stage can be positive, implying that the company breaks the downward trend, or negative trend indicating the continuing deterioration of the company value and a movement downwards, from one stage of the spiral to another. In many real cases, when entering financial distress, the company moves through all the phases of decline (Mueller, 1986).

Financial distress, as characterized by a sharp decline in the company's financial performance and value (Opler \& Titman, 1994), is part of the overall process, which has two important characteristics; moving down the spiral from one stage to another, the sharp decline accelerates, whereas the length of each stage becomes shorter and shorter. The financial performance deterioration can continue longer than the economic failure of the company. The length of insolvency depends on the maturity structure of the firm's debt, whereas default is dependent on the date of maturity, followed by renegotiation and turnaround or liquidation and is, therefore, the shortest stage of financial distress. The challenge facing the financial distress theory is in its inability to recognize adverse processes early enough in order to gain more time to prepare for response. The delayed anticipation in occurrence of financial distress brings in more pressure with time and makes the success of counter measures questionable (Opler \& Titman, 1994). Therefore, the financial distress theory is therefore relevant to the study as it informs the dependent variable, which is sustainability in addition to explaining the causes of the challenges facing the insurance companies.

\section{Empirical Review}

According to Lucky and Nwosi (2015) asset quality is an important measure that is useful in evaluating the performance of an organization. Asset quality measurement entails the measurement of the level and size of credit associated with a company's business. The aim of asset quality measurement is for mainly ascertaining the level of non-performing assets of a company in relation to its total assets.

Siat (2013) notes asset quality as an important parameter that is used to measure the financial strength of a commercial bank. The aim of measuring the quality of assets is to determine the rate of non-performing assets compared to the aggregate assets. Asset quality ratio indicates a company's level of non-performing assets in net advances.

Kaddumi (2015) investigated assets quality management and its impact on profitability and shareholders' value of listed commercial banks in Jordan. Multiple and simple regression analysis were used for data analysis. The results showed that bank's asset quality indicators have a positive impact on the profitability and shareholders value. These results implied that banks' financial 
management should take into consideration the importance of investment diversification to achieve sustainability in its performance.

Cheruiyot (2016) assessed the effect of asset quality on financial performance using profitability of commercial banks operating in Kenya. The study employed a descriptive research design, which enabled the researcher to describe the characteristics of the research variables. The study focused on all the 43 commercial banks operating in the country in 2016 (CBK, 2014).

He concluded that asset quality and profitability of commercial banks in Kenya had a significant and positive relationship. The effect of the loans that were not being repaid to net assets ratio was low; which meant that asset quality of commercial banks in Kenya was positive to profitability.

Adeolu (2014) found asset quality to be significant and positively affected performance of banks. The study data was obtained from the annual reports and records of the six biggest banks recorded on the Nigeria Stock Exchange in light of market capitalization covering 1999 to 2013. To quantify bank's performance and asset quality, the bank utilized proportions since it is an undeniable means for assessing the organizations' level of exercises.

Lucky and Nwosi (2015) evaluated the effect of asset quality on the productivity of the fifteen (15) commercial banks in Nigeria from 1980-2013. A CAMELS criterion for asset quality assessment was utilized to survey the association with the benefit financial performance of Nigerian commercial banks. They concluded that there was a positive relationship between asset quality and productivity. The conclusion was that there is critical connection between resource quality and the gainfulness of the commercial banks. The findings were that the influence on asset quality to the performance of commercial banks in Kenya was positive (Cheruiyot, 2016), while it was significant and positive to performance in Nigerian banks (Adeolu, 2014).

Finally, Lucky and Nwosi (2015) confirms the existence of a positive relationship and asset quality and productivity of commercial banks in Nigeria. Although most of the previous studies were conducted among players in the banking sector, the insurance companies are a key partner in financial sector management and therefore the need for the fourth hypothesis $\mathrm{H}_{0} 4$ that Asset Quality has no influence of sustainability of insurance companies in Kenya.

\section{Conceptual Framework}

The purpose of the conceptual framework is to depict the relationship between Asset Quality, which is the independent variable, and Sustainability, which is the dependent variable (Dodge, 2009). Sustainability of insurance companies responds to the changes Asset Quality parameters (Everitt, 2009). 
INTERNATIONAL JOURNAL OF ACADEMIC RESEARCH IN BUSINESS AND SOCIAL SCIENCES

Vol. 10, No. 5, May, 2020, E-ISSN: 2222-6990 ㄷ 2020 HRMARS

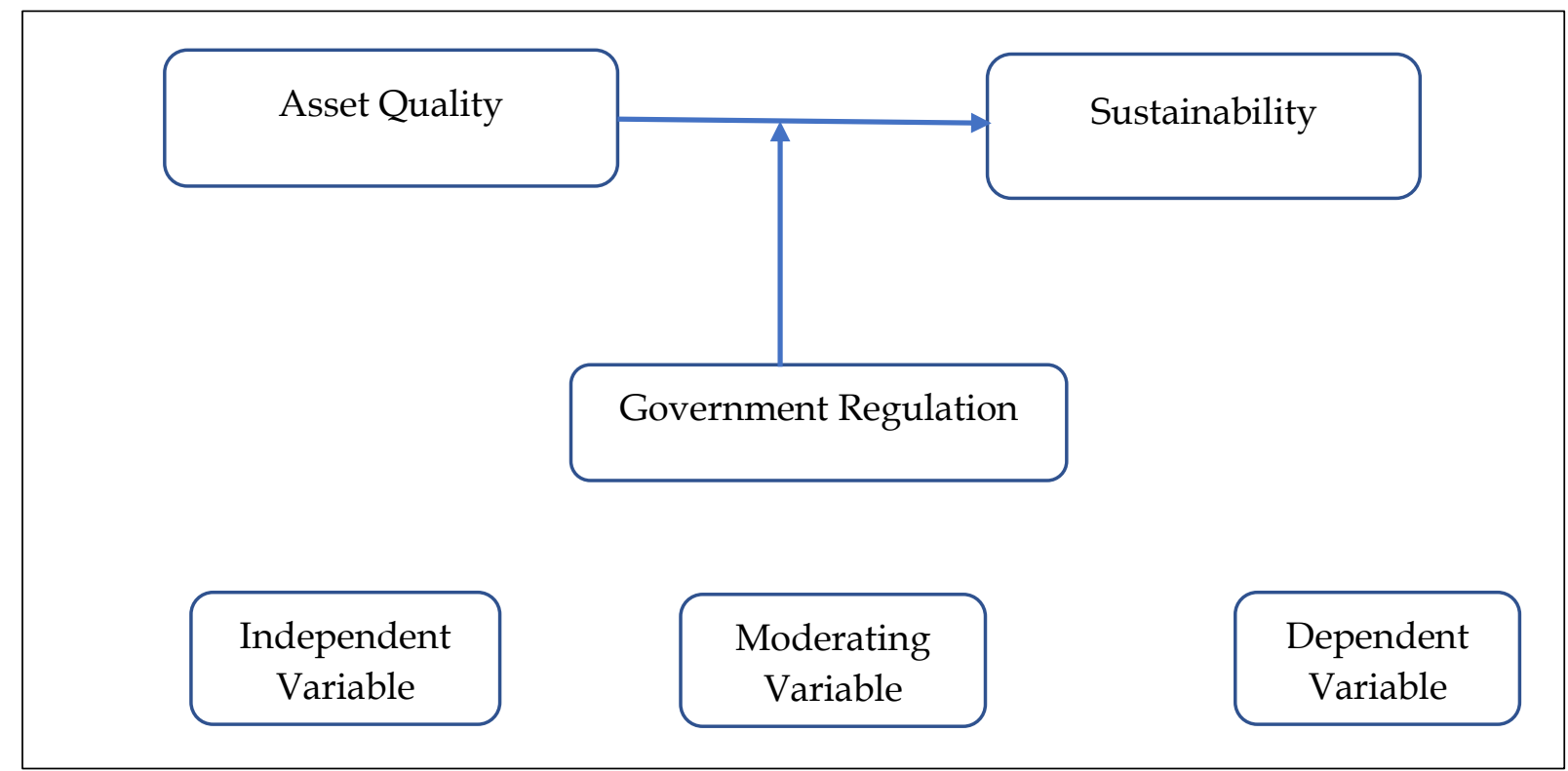

Figure 1. Conceptual Framework for Drivers of Sustainability

\section{Research Methodology}

The study adopted the positivist research philosophy and employed a descriptive research design during the research process. This philosophy was chosen as it emphasizes on objective approach to study and gives importance to quantitative analysis, surveys and experimental research methods. Descriptive research design was the choice for the study as it heled describe the sate of affairs as they are. The target population of the study was the 51 insurance companies as registered by the Insurance Regulatory Authority of Kenya as at 31 ${ }^{\text {st }}$ December 2016, of which the researcher proportionately chose 30 of them from life, general and composite companies. Using purposive sampling procedures for data collection and employing stratified random sampling method, the researcher collected the required data. Data collection instrument was the stratified questionnaire for primary data collection while data collection sheets were used for secondary data. A pilot study before questionnaire deployment ensured their validity and reliability, before distribution by email, followed by a telephone call to the respondents and a research assistant visiting the respondents to collect them.

The period of the study was 2001-2015, a period during which the industry faced turbulence, increased regulation and collapse of several insurance companies. The researcher collected data by sampling 357 staff from senior, middle and junior cadres of staff of the 30 insurance companies. The raw data was cleaned, edited, coded and analyzed using SPSS tool to generate descriptive and inferential statistics while secondary data was collected using data collection sheets. Data analysis using multiple regression analysis was performed to determine the relationship of each of the independent variables to the dependent variable. The researcher used descriptive statistics such as the mean, standard deviation and frequencies to analyze the data. 
INTERNATIONAL JOURNAL OF ACADEMIC RESEARCH IN BUSINESS AND SOCIAL SCIENCES

Vol. 10, No. 5, May, 2020, E-ISSN: 2222-6990 @ 2020 HRMARS

\section{Results}

\section{Descriptive Results}

The study sought to examine how asset quality influenced sustainability of insurance companies in Kenya. Data was collected from the respondents who indicated their levels of agreement to various study questions using a five point Likert scale. A further grouping was done for the purposes of interpretation with $4 \& 5$ (agree and strongly agree) being grouped together as agree, 1 \& 2 (strongly disagree and disagree) were grouped as disagree while 3 was indicated as neutral. The descriptive of the influence of asset quality on performance and sustainability of insurance companies in Kenya are presented in Table 1 which indicates that $77.1 \%$ of the respondents supported that the company's credit control policy improves the quality of premiums debtors ensures its sustainability. Kaddumi (2015) who concluded that credit control policies improves company's profitability supports these findings. The results (73.2\%) of the respondents agreed that the company's doubtful debts provision policy enhances company sustainability. Further, $63.1 \%$ of the respondents support that the company should be listing its defaulting clients with the credit reference bureaus to enhance its sustainability in Adeolu (2014) who argued of the importance for an organization to list its defaulting clients with credit reference bureaus to enhance its performance.

In addition, $77.5 \%$ of the respondents agreed that the company's annual credit rating exercise with rating agencies enhances its sustainability in line with Kaddumi (2015) who argued that companies should implementing credit rating exercises to enhance their sustainability. Finally, $85.5 \%$ of the respondents agreed that the inclusion of credit management in senior management meetings enhances the company's sustainability while, $57.6 \%$ of the respondents agreed that the inclusions of credit management in board evaluation enhances the company's sustainability. These findings were consistent with that of Lucky and Nwosi (2015) who found that credit management have a positive and significant effect with profitability.

On a five point scale, the average mean of the responses was 3.8 which means that majority of the respondents agreed with the statements; however, the answers were varied as shown by a standard deviation of 1.04. Many insurance companies have collapsed in the country (Table 2.4) during the period under study. The collapse of these companies resulted from these companies holding illiquid assets making it difficult for insurance companies to pay policyholder claims as and when they fell due. The insurance companies have credit control departments and excellent doubtful debt provisioning policies, but their levels of unpaid premiums is quite high and with the RBC supervision, all premium debts over 30 days old attract a 100\% capital charge. The credit control staff are members of senior management meetings and the board members have credit control as an agenda in their meetings. The severe competition for market share has led to uncontrolled credit to customers who end up not meeting their commitments to pay and also may show a level of management override where the credit control staff have no strong mandates to run the function. In the country, most of the insurance companies are moving towards credit rating, however, the role of credit rating agencies in the quality of business underwritten by a particular insurance company be yet to be established. 
INTERNATIONAL JOURNAL OF ACADEMIC RESEARCH IN BUSINESS AND SOCIAL SCIENCES

Vol. 10, No. 5, May, 2020, E-ISSN: 2222-6990 @ 2020 HRMARS

\section{Factorability Test for Asset Quality}

\section{Sampling adequacy for Asset Quality}

To examine whether the data collected was adequate and appropriate for inferential statistical tests such as the factor analysis, multiple linear regression analysis and other statistical tests, two main tests were performed namely; Kaiser-Meyer-Olkin (KMO) Measure of Sampling Adequacy and Barlett's Test of Sphericity. For a data set to be regarded as adequate and appropriate for statistical analysis, the value of KMO should be greater than 0.5 (Field, 2000). The KMO Sampling Adequacy and Bartlett's Sphericity Tests on influence of asset quality on performance and sustainability of insurance companies in Kenya. The KMO statistic was 0.635 which was significantly high; that is greater than the critical level of significance of the test, which was set at 0.5 (Field, 2000).

In addition to the KMO test, the Bartlett's Test of Sphericity was also highly significant (Chi-square = 341.807 with 15 degree of freedom, at $p<0.05$ ). These results provide an excellent justification to conduct further statistical analysis.

\section{Communalities for Asset Quality}

Table 1: Communalities for Asset Quality

\begin{tabular}{llrc}
\hline Parameter & Statement & Initial & Extraction \\
\hline AQ 6 & $\begin{array}{l}\text { The inclusions of credit management in board evaluation enhances the } \\
\text { company's sustainability }\end{array}$ & 1 & 0.778 \\
AQ 5 & $\begin{array}{l}\text { The inclusion of credit management in senior management enhances } \\
\text { the company's sustainability. }\end{array}$ & 1 & 0.651 \\
AQ 3 & $\begin{array}{l}\text { The company listing of defaulting clients with the credit reference } \\
\text { bureaus enhances its sustainability }\end{array}$ & 1 & 0.679 \\
AQ 4 & $\begin{array}{l}\text { The company's annual credit rating exercise with rating agencies } \\
\text { enhances its sustainability }\end{array}$ & 1 & 0.575 \\
AQ 1 & $\begin{array}{l}\text { The company's credit control policy to improve quality of premiums } \\
\text { debtors ensures the its sustainability }\end{array}$ & 1 & 0.521 \\
AQ 2 & $\begin{array}{l}\text { The company doubtful debts provision policy enhances its sustainability } \\
\text { The }\end{array}$ & 1 & $\mathbf{0 . 1 9 9}$ \\
\hline
\end{tabular}

According to Kaiser (1974), factor-loading values that are greater than 0.4 should be accepted and values below 0.5 should lead to correction of more data to help researcher to determine the values to include. Values between 0.5 and 0.7 are mediocre, values between 0.7 and 0.8 are good, values between 0.8 and 0.9 are great, and values above 0.9 are superb. Factor analysis was conducted on statements regarding asset quality and one statement had a coefficient of less than 0.4 and hence was dropped for descriptive and regression.

\section{Reliability Test for Capital Adequacy}

The study tested reliability for capital adequacy measures using Cronbach's Alpha Test of Reliability. The Cronbach's Alpha reliability coefficient estimates internal consistency by determining how all items on a test relate to all other items and to the total test-internal coherence of data. The reliability concept is expressed as a coefficient between 0.0 and 1.00, the higher the coefficient, the more reliable is the test. According to Kaiser (1974), factor-loading values that are greater than 0.5 should be accepted and values below 0.5 should lead to correction of more data to help researcher to determine the values to include. Values between 0.5 and 0.7 are mediocre, values between 0.7 and 
INTERNATIONAL JOURNAL OF ACADEMIC RESEARCH IN BUSINESS AND SOCIAL SCIENCES

Vol. 10, No. 5, May, 2020, E-ISSN: 2222-6990 @ 2020 HRMARS

0.8 are good, values between 0.8 and 0.9 are great, and values above 0.9 are superb. The Asset Quality component matrix are presented in Table 4.

According to Kaiser (1974), factor-loading values that are greater than 0.5 should be accepted and values below 0.5 should lead to collection of more data to help researcher to determine the values to include. Values between 0.5 and 0.7 are mediocre, values between 0.7 and 0.8 are good, values between 0.8 and 0.9 are great, and values above 0.9 are superb. Factor analysis was conducted on statements regarding asset quality and one statement had a coefficient of less than 0.5 and hence was dropped for descriptive and regression.

\section{Total Variance Explained}

The researcher performed further analysis by rotating the Sums of Squared Loadings values to get the distribution of the variance after the varimax rotation. Varimax rotation tries to maximize the variance of each of the capital adequacy factors, so the total amount of variance accounted for was redistributed over the two extracted factors. Rotation Sums of Squared Loadings values as presented in Table 5 are the distribution of the variance after the varimax rotation.

Table 2: Total Variance Test Results

\begin{tabular}{lrrrrrr}
\hline Component & \multicolumn{2}{l}{ Initial Eigenvalues } & \multicolumn{3}{c}{ Rotation Sums of Squared Loadings } \\
& Total & \% of Variance & Cumulative \% & \multicolumn{1}{l}{ Total } & \% of Variance & Cumulative \% \\
\hline AQ 6 & 2.380 & 39.669 & 39.669 & 2.380 & 39.669 & 39.669 \\
AQ 5 & 1.023 & 17.058 & 56.727 & 1.023 & 17.058 & 56.727 \\
AQ 3 & 0.968 & 16.136 & 72.862 & 0.968 & 16.136 & 72.863 \\
AQ 4 & 0.887 & 14.786 & 87.649 & 0.887 & 14.786 & 87.649 \\
AQ 1 & 0.420 & 6.997 & 94.646 & 0.420 & 6.997 & 94.646 \\
AQ 2 & 0.321 & 5.354 & 100.000 & & & \\
\hline
\end{tabular}

The study results conclude that the five extracted factors out of the six components explained $94.646 \%$ of the total variations.

\section{Scree Plot for Asset Quality}

The study obtained scree test results by plotting the latent roots, eigenvalue, against the factors in order of extraction. From the fifth factor on, the line is almost flat, meaning the each successive factor is accounting for smaller and smaller amounts of the total variance.

\section{Rotated Component Matrix for Asset Quality}

The researcher rotated the component of asset quality for further analysis as per Table 3 below which imply that AQ1, AQ2, AQ3 and AQ4 can be combined into one factor. Further, AQ5 and AQ6 can also be combined into one factor. 
INTERNATIONAL JOURNAL OF ACADEMIC RESEARCH IN BUSINESS AND SOCIAL SCIENCES

Vol. 10, No. 5, May, 2020, E-ISSN: 2222-6990 @ 2020 HRMARS

Table 3: Rotated Component Matrix

\begin{tabular}{|c|c|c|c|}
\hline Parameter & Statement & 1 & 2 \\
\hline AQ 1 & $\begin{array}{l}\text { The company's credit control policy to improve quality of } \\
\text { premiums debtors ensures the its sustainability }\end{array}$ & 0.654 & \\
\hline$A Q 2$ & $\begin{array}{l}\text { The company listing of defaulting clients with the credit reference } \\
\text { bureaus enhances its sustainability }\end{array}$ & 0.819 & \\
\hline AQ 3 & $\begin{array}{l}\text { The company's annual credit rating exercise with rating agencies } \\
\text { enhances its sustainability }\end{array}$ & 0.743 & \\
\hline AQ 4 & $\begin{array}{l}\text { The inclusion of credit management in senior management } \\
\text { enhances the company's sustainability. }\end{array}$ & 0.771 & \\
\hline AQ 5 & $\begin{array}{l}\text { The company doubtful debts provision policy enhances its } \\
\text { sustainability }\end{array}$ & & 0.415 \\
\hline AQ 6 & $\begin{array}{l}\text { The inclusions of credit management in board evaluation } \\
\text { enhances the company's sustainability }\end{array}$ & & 0.880 \\
\hline
\end{tabular}

Therefore, Asset quality analysis will be on two factors. Factor one (1) will consist of credit control policy, list of defaulting clients, credit rating exercise and participation of credit management in senior management meetings. Factor two (2) will consist of doubtful debts provision policy and credit management being included in the evaluation criteria of a company's board.

\section{Correlation Test}

The results of the correlation between asset quality and sustainability of insurance companies in Kenya are presented in Table 7 suggesting that a company's credit control policy have a positive and significant effect with sustainability of insurance companies $(r=0.329, p=0.000)$ in line with Kaddumi (2015) who concluded that credit control policies improves company's profitability.

The practice of listing of defaulting clients with the credit reference bureau have a positive and significant effect with sustainability of insurance companies $(r=0.498, p=0.000)$ which is supported by Adeolu (2014) who argued that it is important for an organization to list its defaulting clients with credit reference bureaus to enhance their performance. Further the company's annual credit rating exercise have a positive and significant effect with sustainability of insurance companies $(r=0.364$, $\mathrm{p}=0.000$ ) as supported by Kaddumi (2015) who argued that companies should implementing credit rating exercises to enhance their sustainability.

In addition, credit management staff representation in senior management meetings have a positive and significant effect with sustainability of insurance companies $(r=0.498, p=0.000)$ as supported by Lucky and Nwosi (2015) who found that credit management have a positive and significant effect with profitability. Further, credit management targets being part of the board evaluation have a positive and significant effect with sustainability of insurance companies $(r=0.189, p=0.002)$ in line with the findings by Lucky and Nwosi (2015) who found that credit management have a positive and significant effect with profitability. 
INTERNATIONAL JOURNAL OF ACADEMIC RESEARCH IN BUSINESS AND SOCIAL SCIENCES

Vol. 10, No. 5, May, 2020, E-ISSN: 2222-6990 @ 2020 HRMARS

\section{Regression Analysis}

Regression analysis was used to examine whether asset quality can be used to explain sustainability of the insurance companies in Kenya. The regression results presented on Table 4 present the fitness of model used for the regression analysis in explaining the study phenomena.

Table 4: Model Fitness for Asset Quality

\begin{tabular}{lllll}
\hline Variables & $\mathbf{R}$ & $\mathbf{R}^{2}$ & Adjusted $\mathbf{R}^{2}$ & $\begin{array}{l}\text { Std. Error of the } \\
\text { Estimate }\end{array}$ \\
\hline Coefficients & 0.649 & 0.422 & 0.411 & 0.4544 \\
\hline
\end{tabular}

Asset Quality was found to be satisfactory in explaining sustainability of insurance companies as supported by coefficient of determination also known as the $\mathrm{R}^{2}$ of $42.2 \%$. The $\mathrm{R}^{2}$ means that the model fitness found out that Capital adequacy explain $42.2 \%$ of the variations in the dependent variable which is sustainability of the insurance companies. The analysis of variance for asset quality are presented in Table 5.

Table 5: ANOVA for Asset Quality

\begin{tabular}{lccccc}
\hline Measure & Sum of & \multicolumn{3}{c}{ Mean } & Sig. \\
\hline Regression & Squares & Df & Square & F & 0.000 \\
Residual & 40.378 & 5 & 8.076 & 39.095 & \\
Total & 55.36 & 268 & 0.207 & & \\
\hline
\end{tabular}

The analysis of the variance (ANOVA) results indicated that the model was statistically significant, implying that the Asset Quality is a good predictor of sustainability of insurance companies. The findings are supported by an F-statistic of 39.095 and the reported p-value (0.000) which was less than the conventional probability of 0.05 significance level.

The study tested the null hypothesis that Asset Quality did not influence the sustainability of insurance companies in Kenya. The Null hypothesis was tested by using multiple linear regression. The acceptance/rejection criteria was that, if the $p$ value is greater than 0.05, the $H_{\circ} 1$ was not rejected but if was less than 0.05 , the $\mathrm{H}_{\mathrm{o}}$ fails to be accepted. The null hypothesis was that there is no significant relationship between asset quality and sustainability of insurance companies in Kenya. Results in Table 6 above show that the p-value was $0.000<0.05$. The null hypothesis was rejected, with the conclusion that there was a significant relationship between asset quality and sustainability of insurance companies in Kenya. These findings were consistent with that of Cheruiyot (2016) who concluded that there is a great positive relationship between asset quality and profitability of commercial banks in Kenya. The regression of coefficient test results for asset quality are presented on Table 10 below. 
INTERNATIONAL JOURNAL OF ACADEMIC RESEARCH IN BUSINESS AND SOCIAL SCIENCES Vol. 10, No. 5, May, 2020, E-ISSN: 2222-6990 @ 2020 HRMARS

Table 10: Regression of Coefficients for Asset Quality

\begin{tabular}{lcccc}
\hline Variable & B & Std. Error & t & Sig. \\
\hline Company's Credit Control Policy & 0.027 & 0.040 & 0.678 & 0.498 \\
Listing of Defaulting Clients & 0.198 & 0.042 & 4.775 & 0.000 \\
$\begin{array}{l}\text { Company's Annual Credit Rating Exercise } \\
\text { Credit Management in Senior }\end{array}$ & 0.009 & 0.042 & 0.207 & 0.836 \\
Management & 0.298 & 0.041 & 7.348 & 0.000 \\
Credit Management in Board Evaluation & 0.046 & 0.022 & 2.146 & 0.033 \\
\hline
\end{tabular}

The results of the company's credit control policy have a positive and insignificant effect with sustainability of insurance companies $(r=0.329, p=0.498)$ in line with Kaddumi (2015) who concluded that credit control policies improves company's profitability. The results, further revealed that listing of defaulting clients with the credit reference bureau have a positive and significant effect with sustainability of insurance companies $(r=0.198, p=0.000)$ as supported by Adeolu (2014) who argued that it is important for an organization to list its defaulting clients with credit reference bureaus to enhance their performance.

The findings further revealed that company's annual credit rating exercise have a positive and insignificant effect with sustainability of insurance companies $(r=0.009, p=0.836)$ which is supported by Kaddumi (2015) who argued that companies should implementing credit rating exercises to enhance their sustainability. In addition the results revealed that credit management in senior management have a positive and significant effect with sustainability of insurance companies $(r=$ 0.298, p=0.000) which is consistent with that of Lucky and Nwosi (2015) who found that credit management have a positive and significant effect with profitability. The results also revealed that credit management in board evaluation have a positive and significant effect with sustainability of insurance companies ( $r=0.046, p=0.033$ ) as supported by Lucky and Nwosi (2015) who found that credit management have a positive and significant effect with profitability.

\section{Regression Model}

$\mathrm{Y} 4=1.878+0.198 \mathrm{Dc}+0.298 \mathrm{Cmm}+0.046 \mathrm{Cmb}+\varepsilon$

where Y4 = Sustainability, Dc - Listing of Defaulting Clients, Cmm - Credit Management in Senior Management, $\mathrm{Cmb}$ - Credit Management in Board Evaluation and $\varepsilon$ - Error term.

\section{Conclusions and Recommendations}

\section{Summary of Findings}

The objective of the study was to determine how asset quality influenced sustainability of insurance companies in Kenya. Most of the insurance companies have credit control policies, which had very insignificant influence on an insurance company's sustainability. The lack of significant influence on sustainability may be attributable to lack enforcement resulting from little support from management, the board of directors and even the regulator as supported by Kadduni (2015).

A firm regulatory framework, requiring brokers to have secured accounts with insurers or forbids them from premiums collections in their name, is required for an enhanced sustainability of the 
Kenyan insurance industry, which is supported by Lucky and Nkwosi (2015). This is further in line with the revised insurance act and IRA guidelines. It will improve underwrite cash flows and asset quality. Further, listing of insurance company's defaulting clients with the credit reference bureaus might not have any positive influence in the company's sustainability. The insurance companies have to come up with a methodology for determining their client's credit worthiness and the level of credit they are willing to extend to each of their clients and have ability to absorb in case of default, which is in line with the conclusions of Adeolu (2014).

In addition, the insurance companies that conducted annual credit rating and had credit management staff participate in senior management meetings and had credit control incorporated in board performance evaluation goals, suggesting that leadership considered credit management and credit rating as importance facets of their companies' performance, which is supported by Siat (2013). The regression and correlation results revealed that asset quality had a positive and significant influence on sustainability of insurance companies in Kenya as supported by Lucky and Nkwosi (2015).

The null hypothesis, $\mathrm{H}_{0}$ : Asset Quality does not influence sustainability of Insurance Companies in Kenya; was rejected, confirming the existence of a significant but positive relationship between asset quality and sustainability of insurance companies. Some of the insurance companies have collapsed as they had invested in illiquid asset classes that could not be easily converted into cash to pay for maturing liabilities, suggesting that they held assets of poor quality that did not match their liabilities in terms of maturities and liquidity. Therefore, companies should develop asset - liability-matching policies. These asset liability-matching policies should be reviewed frequently to ensure alignment to

\section{Conclusions}

The Asset Quality variable was found to have a positive and significant effect on sustainability of insurance companies in Kenya. The insurance companies that have credit control policies improve the quality of premiums debtors, though its impact on sustainability is insignificant. Further, The insurance companies act of listing of their defaulting clients, with the credit reference bureaus enhances its sustainability through stopping bad credit and attracting more and new business as the rating improves the marketing standing and credibility.

The annual credit rating exercises with rating agencies was found to have insignificant influence on an insurance companies quality of assets. The results further concluded that inclusions of credit management in senior management meetings and being part of board performance evaluation measures enhances the company's sustainability as credit management is given limelight at the most senior forums of the organization.

\section{Recommendations}

The study recommends that insurance companies should elevate credit management as a critical function in the determination of asset quality of their companies. The elevation should be through making credit management parameters part of performance management in senior management and board evaluations. To enhance the quality of the clients in the industry and ensure bad credit does not move from one insurance company to another, all defaulting clients should be listed with the credit reference bureaus. The credit control policies may not enhance asset quality if they are not 
INTERNATIONAL JOURNAL OF ACADEMIC RESEARCH IN BUSINESS AND SOCIAL SCIENCES

Vol. 10, No. 5, May, 2020, E-ISSN: 2222-6990 @ 2020 HRMARS

enforced while annual credit rating will aid in attracting business but both have no significant influence on asset quality and sustainability of insurance companies.

The risk based supervision framework was adopted in the country in 2015 but the level of compliance has been quite low, as the minimum has been set at $100 \%$, with the dates of full compliance being extended to 2020. The adoption of the risk-based supervision is a step in the right direction. The model does not capture some factors that enhance an insurance company's performance. The combined factors of sustainability and agility such as technological adoption and advancement, measures adopted by the insurance companies to combat climate change have not been incorporated. The IRA monitors and approves the insurance companies senior management and directors through the fit and proper process, but limited information's is captured in the annual review either through a sustainability or agility index or even bringing a management capability index. Therefore, it would be of interest for IRA to open up the RBC measures to bring in agility, sustainability and management indices. RBC regulation should be geared towards adequacy of capital, improved enterprise risk management practices and management capability which if addressed, then the quality of assets should be addressed, as government moderation does not influence the same. These measures should prioritize on capital adequacy, sensitivity to risk, asset quality and management capability in that order to enhance performance of insurance companies in terms of profitability, people and planet earth in terms of climate change.

\section{References}

Adeolu, M. A. (2014). Asset Quality and Bank Performance: A Study of Commercial Banks in Nigeria. Research Journal of Finance and Accounting, pp. 39-44.

Baxter, N. (2007). Leverage, Risk of Ruin and the Cost of Capital. The Journal of Finance, pp.395-403. BMI. (2014a). BMI Insurance Kenya Report Q2 2014. Business Monitor International

BMI. (2014c). BMI Comparative Data. Business Monitor International.

Brigham, E. F., \& Ehrhardt, M. C. (2004). Financial Management: Theory and Practice, 11th Edition, South-Western College Publishers, New York.

Boregowda, R. (2014). Debt Equity Mix and Firm Performance: Evidence from Malaysian Listed Companies. Procedia-Social and Behavioral Sciences, Vol. 65, pp. 156-166.

CBK. (2014). Managerial Ownership and Agency Conflicts: A Non-Linear Simultaneous Equation Analysis of Managerial Ownership, Risk Taking, Debt Policy, and Dividend Policy, Journal of Financial Review, pp. 19-36.

Chen, F. X., \& Wang, W. (2011). Research on the Relationship among Government Regulations, Strategy Preference and Manufacturing Performance. Journal of Service Science and Management, pp. 37-43

Cheruiyot, K. S. (2016). Impact of Internet Banking on Financial Performance of Commercial Banks in Kenya. Unpublished Master's Thesis from the University of Nairobi Depository.

Danso, A., \& Adomako, S. (2014). The Financing Behavior of Firms and Financial Crisis. Managerial Finance, Managerial finance, pp.1159-1174.

Field, R. (2006). Performance Management in Insurance Corporations. Journal of Business Administration Online, pp. 135-144.

Freeman, R. E. (1984). Strategic Management: A Stakeholder Approach. Boston, MA.

Jones, J. (2011). Sustainability and Risk Management. The Insurance Industry and Sustainability. 
INTERNATIONAL JOURNAL OF ACADEMIC RESEARCH IN BUSINESS AND SOCIAL SCIENCES

Vol. 10, No. 5, May, 2020, E-ISSN: 2222-6990 @ 2020 HRMARS

Kaddumi, T. A. (2015). Impact of Assets Quality Management on Profitability and Shareholders' Value. The case of Jordanian Listed Commercial Banks. American Academic \& Scholarly Research Journal, pp. 108-122

Kariuki, F. K. (2015). Sustainability in the Financial Sector in Kenya. Kenya Bankers Association Working Papers.

Lucky, A. L., \& Nwosi, A. A. (2015). Asset Quality and Profitability of Commercial Banks: Evidence from Nigeria. Research Journal of Finance and Accounting, 6 pp. 26-34.

Mercer. (2014). Business and Workforce Challenges in the Global Insurance Industry

Siat, M. J. (2013). Comparative Financial Performance of Islamic Banks and Conventional Banks in Kenya (Doctoral dissertation, University of Nairobi). 